\title{
Dry Ports As Extensions of Maritime Deep-Sea Ports: A Case Study of Vietnam
}

\author{
NGUYEN C L* , NOTTEBOOMT**
}

\begin{abstract}
This paper focuses on dry port as a key notion in port-hinterland development. We first discuss the concept of dry port by reviewing existing literature. Then, we explore the reasons behind the emergence and development of inland node systems in different geographical, economic and institutional contexts. Next, the paper presents a classification of dry ports based on a multitude of factors and dimensions and the respective benefits to different parties. The study then focuses on the specific characteristics of dry ports and associated transport networks in developing countries.

In the last part, we present a case study on the dry port system in Vietnam by reviewing the seaport and inland transport system and analyzing the current status of inland terminals in Vietnam. To conclude, a SWOT analysis is presented with regard to the development of the dry port network in Vietnam, followed by recommendations for policy makers.
\end{abstract}

Key Words: Dry ports, gateway ports, Vietnam, intermodality, SWOT analysis

Submission Date: 05/02/2016 Revision Date: 05/04/2016 Acceptance Date: 11/04/2016

* Faculty of Applied Economics, University of Antwerp, Antwerp, Belgium Faculty of Navigation, Vietnam Maritime University, Hai Phong, Vietnam

** Transportation Management College, Dalian Maritime University, Dalian, Liaoning, China Antwerp Maritime Academy, Antwerp, Belgium

Faculty of Applied Economics, University of Antwerp, Antwerp, Belgium

* Corresponding author, email address: theo.notteboom@gmail.com 


\section{Introduction}

The emergence of dry ports is considered as a key outcome of the containerization trend and the increasing integration between seaports and hinterland networks. Within the supply chain, dry ports might work as inland hubs to facilitate the movement of cargo in the hinterland, or extensions of seaports to relieve the burden of limited capacity, natural constraints and diseconomies of scale such as congestion or environmental issues. Over the last decades, many studies have been carried out on dry ports. By consolidating, comparing and filtering this vast literature, the paper aims to discuss the reasons behind the emergence and development of dry ports and their role in supply chains. Then we focus on identifying characteristics of dry port system in developing countries.

In the last part, we develop a case study on Vietnam in view of evaluating its ability of developing a dry port system. The country possesses huge advantages in maritime and inland transportation thanks to a long natural coastline and its important location in economic corridors in the Greater Mekong sub region. Maritime container traffic in Vietnam experienced a strong growth from 100.000 TEU in 1991 to 6.588 .805 TEU in 2013 (The World bank, 2014). However, total logistics costs account for about 25 percent of Vietnam's GDP, pointing to the inefficiency of the logistics system and poor inland transportation. Recognizing those potentials and problems, the Vietnamese government is working on long-term strategies to develop the inland node system with a horizon of 2030. By analyzing the strengths, weaknesses, opportunities and threats (SWOT) of the country, and learning from best practices of dry port development in other countries, the case study aims to identify the most suitable network model and to put forward key suggestions for the development of the dry port system in Vietnam.

\section{The Concept of Dry Port}

\subsection{Terminologies}

A variety of dry port definitions are used in different studies. Notteboom \& Rodrigue (2009) synthesized more than ten terms related to inland nodes, with many of them having more than one definition. The terms of inland clearance depot (ICD) or inland custom depot focus on the function of providing customs clearance as defined by UNCTAD (1991): "a terminal located in the hinterland of a gateway port and serving as a dry port for custom examination and clearance of cargoes, thereby eliminating customs formalities at the 
seaports". This definition is similar to the definition of ICD by Economic Commission for Europe (1998) or Roso (2005). In contrast, the terms inland terminal as defined by UNCTAD (1982), inland container depot by Roso (2005), Jarkemskis \& Vasiliauskas (2007) and Roso et al. (2009) and inland port by Economic Commission for Europe (2001) emphasize the primary role of inland nodes as intermodal terminals, where handling and storage facilities are equipped to synchronize cargo movement between different inland transport modes. The term dry port is used in a supply chain perspective to express an integrated logistics site, which is best summarized in Roso et al. (2009)'s definition: "an inland intermodal terminal that is directly connected to seaport(s) with high capacity transport mean(s), where customers can leave/pick up their standardized units as if directly to a seaport". This definition shows similarities with the terms freight villages or logistics parks, also known as platformes logistiques in France, GVZ in Germany, ZAL in Spain or interporti in Italy (Notteboom \& Rodrigue, 2009; Monios \& Wang, 2013).

\subsection{Drivers behind the emergence and development of dry ports}

The uses of inland nodes are pragmatic (Veenstra et al, 2012) since different regions have their own reasons to develop dry ports. The drivers of dry port development can be categorized into three main points, including seaport constraints, hinterland access and economic zone facilitation.

Many gateway ports are facing numerous development constraints. The most common issues in seaports are land availability, and diseconomies of scale in the form of congestion and environmental problems. Facing those constraints, many seaport authorities have developed dry ports as a solution to relieve burdens and improve efficiency and the modal split by shifting space-consuming activities to satellite locations. A clear example of this is the port of Genoa (Caballini \& Gattorna, 2009). In order to solve the problem of land use, the dry port of Rivalta Scrivia, which is beyond the Apennines and $75 \mathrm{~km}$ from the port of Genoa, was developed in 1966 to be the "dry quay" of the seaport. The dry port is connected to the port of Genoa by a daily railway shuttle with high capacity. Activities such as storage, sorting, reception and distribution are moved to the dry port to save port space as well as reduce congestion and other externalities.

Another reason for gateway ports to develop dry ports is to expand hinterland access and gain a stronger competitive position. As discussed by Notteboom \& Rodrigue (2005), many seaports have reached or on the way to reach a phase of port regionalization characterized by a high level of hinterland integration through a system of corridors and inland nodes. This trend is driven by market forces, such as the demand for door-to-door 
services, and can result in hinterland solutions such as 'extend gates' (Veenstra et al., 2012 and Rodrigue \& Notteboom, 2009). After unloading at the sea terminals, containers will be moved directly to the hinterland using high capacity and frequency inland shuttles. By extending the port boundary to key inland locations, market players in seaports not only lower their logistics cost but also get closer to their customers. The imperative component of the extended gate system is to create a link between seaports and dry ports, with high capacity, reliable and frequent services. These locations are extremely important when considering port competition in overlapping hinterland areas. An example of this is discussed by Monios \& Wang (2013). In Central and Western China, the port of Tianjin and the port of Qingdao share an overlapping inland market covering twelve provinces. As a result of growing competition, a number of dry ports are invested in a strategic location and used as marketing tools by those seaports. Similarly, the port of Dalian has been developing its dry ports to secure the inland market in Northeast China. In contrast, in Guangdong province, no dry ports were developed given the domination of the ports of Shenzhen and Hong Kong.

While the first two categories are driven by seaport players, the last reason for dry port development is considered as land-derived. In this case, dry ports are established in the proximity of economic zones in order to facilitate the cargo movement in relation to maritime deep-seaports. Such dry ports are easily found near or inside production bases at developing economies. We will discuss more this category in the Section 2.4.

\subsection{Dry port classification}

Many dimensions can be used to classify dry ports. Roso et al. (2009) classified inland nodes as close, mid-range and distance dry ports. This classification is quite similar to the concepts of satellite terminals, transmodal center and inland load center presented by Notteboom \& Rodrigue (2009). The explanations of those categories are summarized in Table 1.

Close dry ports or satellite terminals are located in the proximity of seaports with strong connections to seaports by rail, barge and or trucks. These dry ports are mostly developed as extensions of seaports. The main role of close dry ports is to relieve the seaports from the burden of space shortage, congestion and environmental issues. With abundant land available, all high space-consuming activities, such as warehousing or sorting, are shifted from seaports to dry ports. The customs clearance procedures could be carried out in these close dry ports.

Mid-range dry ports work as intermodal hubs to consolidate or deconsolidate cargo 
from shippers. It might also work as a transmodal/transloading terminal before the cargo reaches a specific market. Seaports benefits from this type of dry port by increasing hinterland access and getting closer to the customers. Congestion and pollution are tackled by a modal shift from trucks to barges/trains. Additionally, this type of dry ports gives customers more access to maritime services.

The distant dry port is situated in the vicinity of the market, which might be the consuming area in import-based supply chains, or a core production location in export-based supply chains. This type of dry port plays an imperative role in the logistics system of landlocked countries to connect to international markets. In this case, the seaport will benefit from the connection to this type of dry port by gaining access to the inland market.

\section{Table 1.}

Dry port categories and their functions.

\begin{tabular}{c|c|c|c}
\hline & $\begin{array}{c}\text { Close dry } \\
\text { port/satellite terminal }\end{array}$ & $\begin{array}{c}\text { Mid-range dry port// } \\
\text { transloading center }\end{array}$ & $\begin{array}{c}\text { Distant dry port/load } \\
\text { center }\end{array}$ \\
\hline $\begin{array}{c}\text { Development reason } \\
\text { hinterland supply } \\
\text { chain }\end{array}$ & Seaport constraints & Hinterland access & \multicolumn{1}{c}{$\begin{array}{c}\text { Economic zone } \\
\text { facilitation }\end{array}$} \\
\hline Development driver & Sea-driven (outside in) & End point \\
\hline Role & $\begin{array}{l}\text { - Relieve seaports land-driven } \\
\text { from space shortage, } \\
\text { congestion \& } \\
\text { environmental issues } \\
\text { - Handling cargo } \\
\text { - Custom clearance } \\
\text { - Low value added } \\
\text { services }\end{array}$ & $\begin{array}{l}\text { - Transmodal } \\
\text { - Transloading cargoes } \\
\text { - Reduce congestion } \\
\text { - Modal shift } \\
\text { - Consolidation \& } \\
\text { deconsolidation } \\
\text { - Value added services }\end{array}$ & $\begin{array}{l}\text { - Consolidation for } \\
\text { exported cargo } \\
\text { Reduce congestion } \\
\text { - Modal shift } \\
\text { - High value added } \\
\text { services }\end{array}$ \\
\hline
\end{tabular}

Market derived

\section{Direction of hinterland access}

Source: own compilation based on Roso et al. (2009), Notteboom \& Rodrigue (2009), Monios \& Wilmsmeier (2013).

Notteboom and Rodrigue (2009) classified dry ports according to a set of functional standards. The first criterion is the number of inland transport modes handled in the dry port (unimodal, bimodal and trimodal). The second dimension is the primary function of the dry 
ports, including cargo handling, custom clearance, depot, warehousing, value added services, etc. Additionally, dry ports might be categorized by their size, the openness of the node, type of cargo or if they provide direct or indirect transshipment. Rodrigue and Notteboom (2009) introduced the concept of "terminalization" in which terminals are classified into bottleneck-derived, where the inland terminal emerges as a way to deal with capacity limitations in seaports, and buffer-derived, where the function of storage is shifted from warehouses or distribution centers to dry ports.

Dry ports can also be classified according to the actors driving their development (Monios \& Wilmsmeier, 2012), including port authority, port terminal operators, rail operators, public organizations and logistics players. In accordance with the direction of development, dry ports might be sea-driven inland nodes (outside-in development), which are developed by port authority or terminal operators; or land-driven nodes (inside-out development), which are developed by rail operators or the public sector.

\subsection{Dry ports in developing countries}

There are differences in motivations between developed and developing systems when it comes to dry port development. This section aims to discuss the characteristics of dry port systems in developing economies by looking at several case studies, including India (Ng \& Gujar, 2009), Laos (UNESCAP, 2014), Vietnam, South Africa (Cronje et al., 2009) and Nigeria (Garnwa et al. 2009).

In developed systems like in North America and Europe, seaports have reached the phase of regionalization (Notteboom \& Rodrigue, 2005) where port players successfully developed high integrations with their hinterlands by strongly cooperating with inland locations. In contrast, underdeveloped systems have somewhat lost the connection between seaports and inland markets. Specifically, developing countries often rely on the export of raw materials and low technical goods produced in economic zones while importing high value products from developed countries. The long distances between these economic zones and the seaport system results in high logistics costs for export cargo. Thus, inland terminals there are developed by land-based players to facilitate the movement of export cargo. They do not have a good cooperation with gateway seaports and are free to choose the seaport that best meets their needs.

Dry ports in developing countries are likely to be located close to large production bases, or even inside industrial zones. Ng and Cetin (2012) argue that the least-cost model, which is working well in advanced economies, might be insufficient for a developing dry port system. By testing the Centre of Gravity model in the cases of Ahmadabad and Nagpur 
in India, their research showed that dry ports in developing economies might be more "cluster-oriented" than "supply chain-oriented". The reason is that exporting shippers in developing countries are mostly small or medium-sized, and they do not have good control over the long supply chains from their bases to seaports. These shippers prefer local dry ports where they can receive better information, higher flexibility and react faster to changes in demand. The case study on India presented by $\mathrm{Ng}$ and Gujar (2009) further supports this point. In Southern India, Tirupur Inland Container Depot is located around 7 kilometers away from the main textile production zone. In Northern India, Sabarmati Inland Container Depot is situated only 4 kilometers from the production bases of textile, pharmaceuticals, paper, sheet glass, chemicals and agriculture products. Similarly, Nagpur Inland Container Depot facilitates the export of mineral and forest products coming from an economic zone in Central India about 12 kilometers away from the facility. Other examples can be found in the Indochina region (UNESCAP, 2014). Vientiane Dry Port is planned in Laos PDR in order to serve the developing industrial parks of forest products and export them through the east-west corridor using the gateways ports of Thailand and Vietnam. The City Deep Dry Port in South Africa is located within a 50km radius from the centre of the Gauteng area, the most important economic region in the country (Cronje et al., 2009).

Contrary to locating at the end point of the supply chain, dry ports in developing countries could also locate in the middle of the chain for transloading between two transportation systems. Such type of inland terminal is easily found at border locations. For example, Lao Cai ICD is located in the province bordering Vietnam and China to handle transit cargo from China to Hai Phong port (Vietnam). Dry ports in close proximity of seaports are hardly found in developing systems since such kind of dry ports are only sea-driven. The dry port network in developing countries is summarized in Figure 1.

In general, the performance of inland node systems in developing countries is quite inefficient due to several common issues. Firstly, most of the ICDs do not meet all the functions mentioned before. Developed dry ports require integration with seaports through high capacity, flexible and reliable shuttle trains or inland waterway services in order to extract the advantages of intermodality. However, developing systems still heavily rely on road transport to move cargo from/to seaports over mid-range or long distances, which results in high logistics costs, higher risks for congestion and pollution. Industrial zones in developing nations are often scattered across a large area, stimulating the formation of many small dry ports. The study on Nigerian ICDs (Garnwa et al., 2009) also exposed the weakness of trained/experienced human resources and low information system support for inland transportation. 


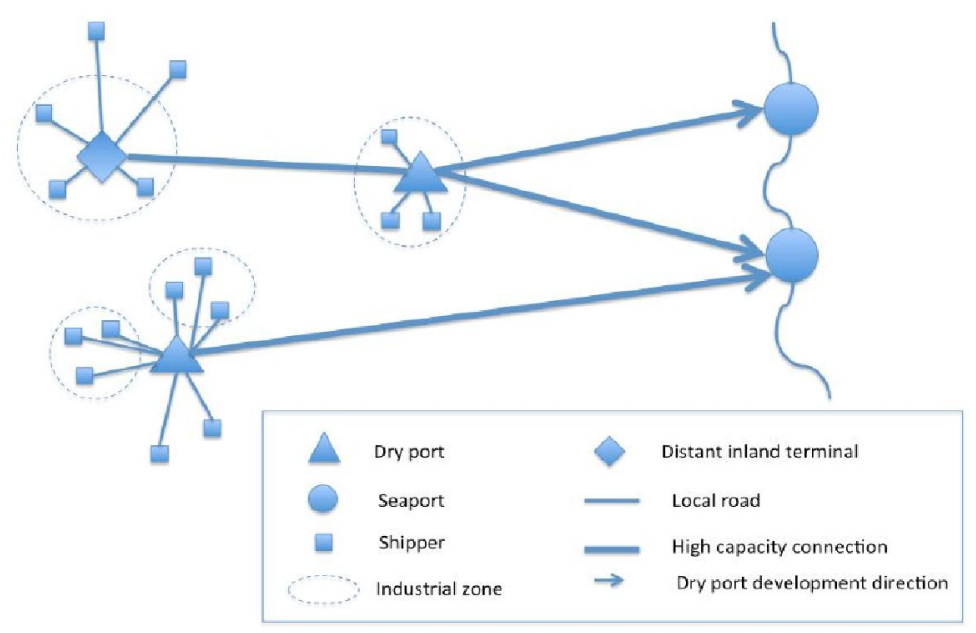

Figure 1.

Dry port network in developing economies.

Source: Authors

\section{The Dry Port System in Vietnam}

\subsection{Overview of container flows in the Vietnamese seaport system}

The Vietnamese seaport system contains 37 seaports with 166 terminals. Two international gateway ports of Vietnam located in Hai Phong and Ba Ria - Vung Tau are being developed to receive vessels of 80.000 to 100.000 DWT or $4000-8000$ TEU (Vietnam Ministry of Transport, 2013). In 1995, total maritime traffic in Vietnam amounted to 37.7 million tons, including 3.4 million tons of container cargo (316,000 TEU). These figures increased to 328.7 million tons in 2013 and 101.1 million tons of containerized cargo or 8.6 million TEU. Around two thirds of container freight went through Southern ports, one third through Northern ports while the Central port group contributed only 3 percent. More detail of container freight evolution in Vietnam is shown in Figure 2.

As synthesized by Nguyễn Thanh Thủy (2010), the lack of deep-water terminals, handling equipment and the short quay length led to the fact that only 1.4 percent of the ports are able to receive ship of more than 50.000 DWT while the rate of dedicated container ports is too low. Most of the container cargo destined for Vietnam has to transship in Singapore or Malaysia. More than 75 percent of the ports are serving vessels of 
less than 20.000 DWT. The average crane efficiency is poor at about 12-25 containers per hour. More than 60 percent of the port terminals are state-owned, which result in stagnation and competition shortage.

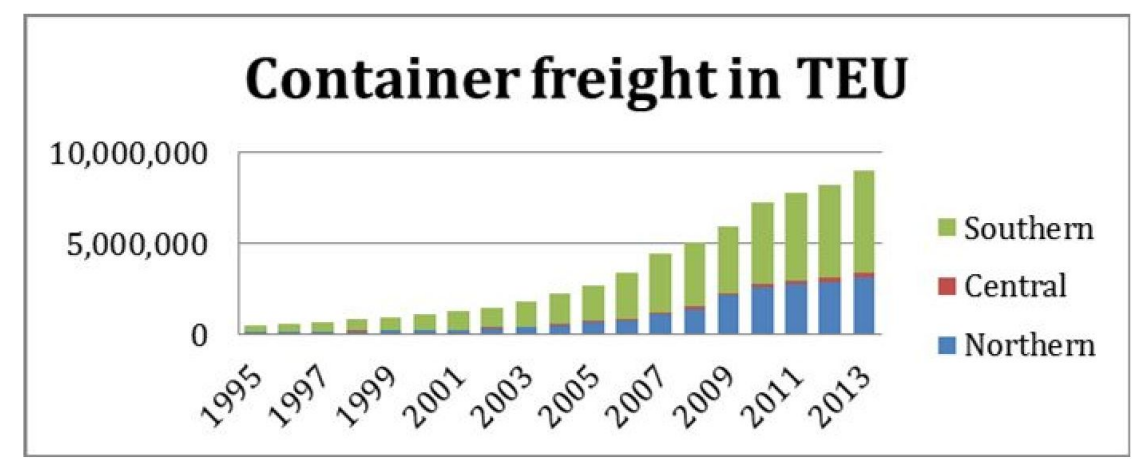

Figure 2.

Container freight in Vietnam between 1995-2013

Source: Vietnam Maritime Administration

The Northern seaport system is dominated by Hai Phong port with roughly 97.6 percent of cargo, while the rest is handled in Cai Lan port (Vietnam Ministry of Transport, 2010). About 95 percent of cargo is moved by road and 5 percent use railway. In Central Vietnam, the ports of Da Nang and Quy Nhon handle close to 90 percent of the containers. Inland transportation in the Central is dominated by road haulage. In Southern Vietnam container flows are concentrated in the Ho Chi Minh City region through the seaport system located along Ho Chi Minh River and Dong Nai River. A third of inland transportation is carried out by inland waterways and two thirds by truck. Rail transportation is very insignificant in the South.

\subsection{Current status of the Vietnamese dry port system}

In Vietnam, the concepts of dry port and logistics center or distribution center can be distinguished at certain levels. Both are important nodal points of transport infrastructure and contribute to improve the efficiency of the logistics system. The main roles of dry ports focus on handling cargo to utilize the advantages of intermodality, having cargo clearance, and working as the destination on the bill of lading to release the congestion at the seaports. Logistics centers improve logistics efficiency by providing the storage, value added, cargo consolidation and deconsolidation for customers. Logistics centers might become dry ports 
if they can handle two or more transport modes and have direct and high capacity connections to seaports. In developed countries, dry ports and logistics center are often combined or co-located in one location. However in developing transport systems these facilities seem to be located separately due to the lack of micro planning and guidance and poor transport infrastructure. In Vietnam, industrial zones are small and scattered which lead to the dispersion of local inland nodes, while the ICDs locations are limited by the poor transport infrastructure. As a result, most ICDs and logistics centers in Vietnam are small and scattered with less than 10 ha area per each. They are located in the proximity of industrial zones to provide logistics services. The system of ICDs is most developed in the South, developing in the North and almost non-existing in the Central part of the country.

In Northern Vietnam, there are six main ICDs (Figure 3) including: Tien Son, Lao Cai, Gia Lam, My Dinh, Thuy Van, Hai Duong, connecting to Hai Phong and Cai Lan ports. All ICDs are mid-range and distant dry ports, located at the distance of between $50 \mathrm{~km}$ (Hai Duong ICD) and $400 \mathrm{~km}$ (Lao Cai ICD) from the seaports. ICDs in the North are all land-driven, located in the proximity of production bases to support inland logistics. Most of them are small with an area of less than $10 \mathrm{ha}$, and offer a limited range of services. The cooperation between ICDs and seaports is also very loose. Total throughput of the dry ports in Northern Vietnam is less than 100,000 TEU, which account for less than one percent of the total container throughput of Hai Phong seaport. Among those dry ports, Lao Cai ICD is the only inland node which has intermodal function. It connects to Hai Phong seaport by Lao Cai- Hanoi - Hai Phong railway, which is part of the Trans-Asian Railway project, to serve the adjacent region and transit cargo from Southwest China.

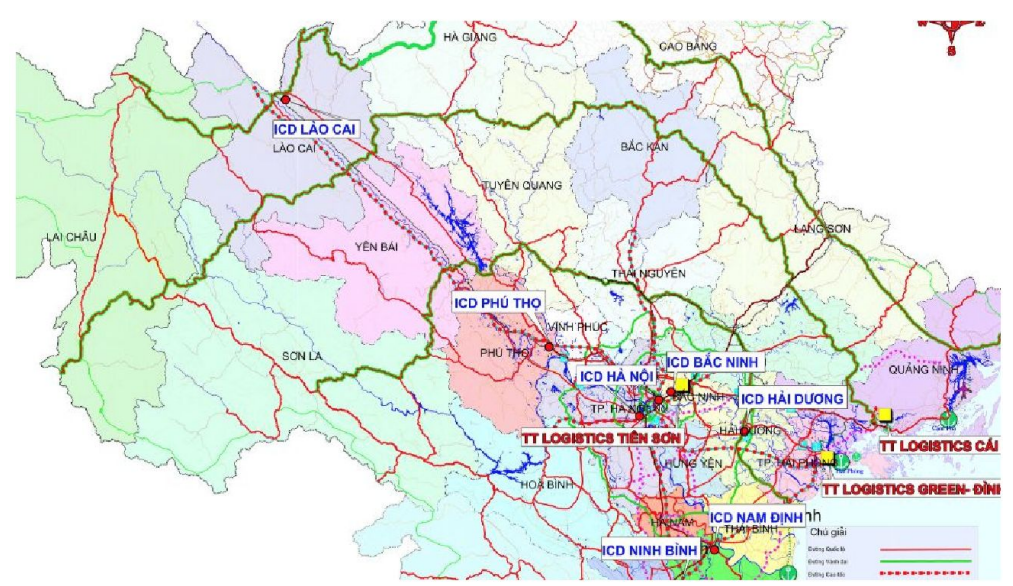

Figure 3.

The ICD system in Northern Vietnam

Source: Vietnam Maritime Administration 


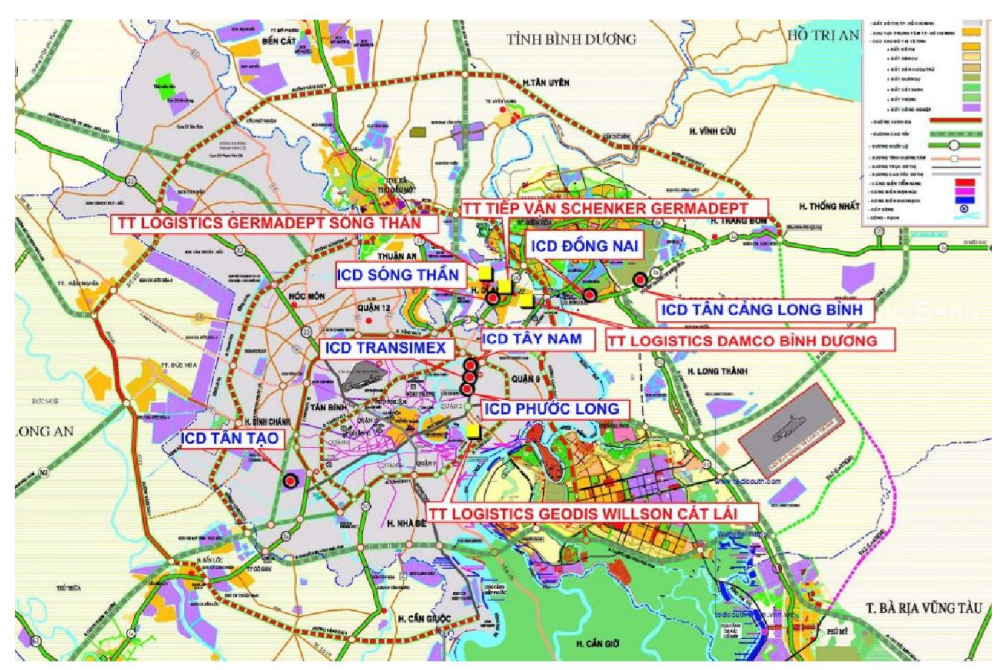

Figure 4.

The ICD system in the Southern Vietnam

Source: Vietnam Maritime Administration

The dry port network in the South (Figure 4) is the most developed system in Vietnam as around 42 percent of containers to seaports pass via the ICD system. Many ICDs are close dry ports, developed by sea actors. As many seaports in the region are located close to the city centers, the development of dry ports in outskirts is necessary to avoid cargo crossing the city. Cargo from industrial zones is moved by road to the inland river ports before shifting to seaports by barge for exporting. The system consists of nine main dry ports: Phuoc Long, New Port Song Than, Transimex, Bien Hoa, Ben Nghe, Song Than, New Port - Long Binh, Sotrans, Phuc Long, Tanamexco. The total area of the dry ports in the South is 300 ha. The largest dry port is Tan Cang -Long Binh with 105 ha. The main ICDs' details in Vietnam are summarized in Table 2.

Table 2.

ICD system in Vietnam

\begin{tabular}{c|c|c|c|c|c|c}
\hline Region & ICD & Province & $\begin{array}{c}\text { Throughput } \\
\text { (TEU/year) }\end{array}$ & $\begin{array}{c}\text { Total area } \\
\text { (ha) }\end{array}$ & $\begin{array}{c}\text { Seaport } \\
\text { connection }\end{array}$ & $\begin{array}{c}\text { Transport } \\
\text { modes }\end{array}$ \\
\hline \multirow{3}{*}{ Northern } & Tien Son & Bac Ninh & 8,400 & 10 & $\begin{array}{c}\text { Hai Phong/ } \\
\text { Quang } \\
\text { Ninh }\end{array}$ & Road \\
\cline { 2 - 7 } & Lao Cai & Lao Cai & $\begin{array}{c}60,000- \\
65,000\end{array}$ & 13.5 & Hai Phong & Rail/Road \\
\hline
\end{tabular}




\begin{tabular}{|c|c|c|c|c|c|c|}
\hline Region & ICD & Province & $\begin{array}{l}\text { Throughput } \\
\text { (TEU/year) }\end{array}$ & $\begin{array}{c}\text { Total area } \\
\text { (ha) }\end{array}$ & $\begin{array}{c}\text { Seaport } \\
\text { connection }\end{array}$ & $\begin{array}{c}\text { Transport } \\
\text { modes }\end{array}$ \\
\hline & Gia Lam & Hanoi & $360-480$ & $\mathrm{n} / \mathrm{a}$ & none & Road \\
\hline & Thuy Van & Hanoi & $\mathrm{n} / \mathrm{a}$ & 3.2 & Hai Phong & Road \\
\hline & Hai Duong & Hai Duong & $\begin{array}{c}6,000-7,20 \\
0\end{array}$ & 12 & $\begin{array}{c}\text { Hai Phong/ } \\
\text { Quang } \\
\text { Ninh }\end{array}$ & Road \\
\hline & My Dinh & Hanoi & 12,000 & 5.5 & Hai Phong & Road \\
\hline \multirow{9}{*}{ Southern } & $\begin{array}{c}\text { Phuoc } \\
\text { Long }\end{array}$ & $\begin{array}{l}\text { Ho Chi } \\
\text { Minh }\end{array}$ & 60,000 & 15 & Vung Tau & $\begin{array}{c}\text { Barge/ } \\
\text { Road }\end{array}$ \\
\hline & Song Than & $\begin{array}{l}\text { Binh } \\
\text { Duong }\end{array}$ & 65,000 & 50 & Vung Tau & Road \\
\hline & Transimex & $\begin{array}{c}\text { Ho Chi } \\
\text { Minh }\end{array}$ & 178,000 & 9 & $\begin{array}{c}\text { Ho Chi } \\
\text { Minh }\end{array}$ & $\begin{array}{c}\text { Barge/ } \\
\text { Road }\end{array}$ \\
\hline & Bien Hoa & Dong Nai & 36,300 & 18 & Dong Nai & $\begin{array}{c}\text { Barge/ } \\
\text { Road }\end{array}$ \\
\hline & Ben Nghe & $\begin{array}{l}\text { Ho Chi } \\
\text { Minh }\end{array}$ & 10,000 & 1.3 & $\begin{array}{l}\text { Ho Chi } \\
\text { Minh }\end{array}$ & $\begin{array}{c}\text { Barge/ } \\
\text { Road }\end{array}$ \\
\hline & $\begin{array}{l}\text { Tan Cang - } \\
\text { Long Binh }\end{array}$ & $\begin{array}{l}\text { Ho Chi } \\
\text { Minh }\end{array}$ & 500,000 & 105 & $\begin{array}{c}\text { Ho Chi } \\
\text { Minh, } \\
\text { Vung Tau }\end{array}$ & Road \\
\hline & Phuc Long & $\begin{array}{l}\text { Ho Chi } \\
\text { Minh }\end{array}$ & $\begin{array}{c}100,000-18 \\
0,000\end{array}$ & 8 & $\begin{array}{l}\text { Ho Chi } \\
\text { Minh }\end{array}$ & $\begin{array}{c}\text { Barge/ } \\
\text { Road }\end{array}$ \\
\hline & Tanamexco & $\begin{array}{l}\text { Ho Chi } \\
\text { Minh }\end{array}$ & $\mathrm{n} / \mathrm{a}$ & 12.5 & $\begin{array}{l}\text { Ho Chi } \\
\text { Minh }\end{array}$ & $\begin{array}{c}\text { Barge/ } \\
\text { Road }\end{array}$ \\
\hline & Sotrans & $\begin{array}{c}\text { Ho Chi } \\
\text { Minh }\end{array}$ & 360,000 & 10 & $\begin{array}{l}\text { Ho Chi } \\
\text { Minh }\end{array}$ & $\begin{array}{c}\text { Barge/ } \\
\text { Road }\end{array}$ \\
\hline
\end{tabular}

Source: Adapted from Vietnam Ministry of Transport (2010).

\section{SWOT analysis for the developing dry port system in Vietnam}

In this section, we carry out a SWOT analysis (strengths, weaknesses, opportunities and threats) for the Vietnamese dry port system (Table 3). 


\section{Table 3.}

SWOT analysis of dry port development in Vietnam

\begin{tabular}{|c|c|}
\hline $\begin{array}{l}\text { Strengths } \\
\text { - Geographical advantages as gateway location } \\
\text { and long coast lines } \\
\text { - Increasing commodity flow: high population; } \\
\text { numerous industrial zones thanks to low } \\
\text { production cost \& government incentives } \\
\text { - Government support: land use } \\
\text { - Natural potential for inland waterway } \\
\text { - Road system was basically invested and } \\
\text { upgraded } \\
\text { - Lessons and experiences from best practices }\end{array}$ & $\begin{array}{l}\text { Opportunities } \\
\text { - Shifting of Multinational Corporations' focuses } \\
\text { to South East Asia (SEA) } \\
\text { - Free Trade Agreements in SEA are entering into } \\
\text { force in } 2018 \\
\text { - Deregulation, privatization of state-owned } \\
\text { enterprises, more attention to PPP } \\
\text { - } 2 \text { deep sea terminals are developed in the South } \\
\text { and the North }\end{array}$ \\
\hline $\begin{array}{l}\text { Weaknesses } \\
\text { - Bottlenecks in sea transportation } \\
\text { - Lack of macro planning: spontaneous } \\
\text { development, hyper-competition, poor modal } \\
\text { split in connection to sea ports, poor ICT and } \\
\text { lack of synchronization } \\
\text { - High bureaucracy \& Low cross } \\
\text { sectors/organizational collaboration } \\
\text { - A dominant role of state-owned enterprises in } \\
\text { the transport sector } \\
\text { - Improper institutional frameworks for dry port } \\
\text { \& railway development } \\
\text { - Poor research practices, lack of collection and } \\
\text { analyses of statistical data } \\
\text { - Limited public funds }\end{array}$ & $\begin{array}{l}\text { Threats } \\
\text { - Competition from other nations in SEA in } \\
\text { attracting FDI } \\
\text { - Port competition in the area } \\
\text { - Threats of overload in current port system } \\
\text { - Conflict in South China Sea }\end{array}$ \\
\hline
\end{tabular}

Source: Authors

\subsection{Strengths}

Vietnam possesses a geographical advantage for trading and transportation since the country is located as a potential gateway to Laos, Northern Thailand, Cambodia and Southwest China. From Southwest China, the cargo can be moved through the corridors Kunming-Lao Cai-Hanoi-Hai Phong-Quang Ninh or Nanning-Lang Son-Hanoi-Hai Phong-Quang Ninh to reach the gateway port of Hai Phong. The East-West corridor connecting Vietnam, Laos, Thailand and Myanmar ends up in Vung Ang port in Central 
Vietnam. The nation has great potential for attracting maritime transport thanks to a long coast of $3.444 \mathrm{~km}$. The current seaport system has been under development for many decades. Many ports in Vietnam have further potential to expand since they suffer from underinvestment and a low operational efficiency.

Secondly, Vietnam has a high demand for inland and sea transportation due to increasing commodity flows. The high population of over 90 million creates a large market and also provides a huge labor force. As in other nations in South East Asia, Vietnam is attracting foreign investment thanks to low production costs from cheap labor, resource availability and government support such as tax incentives, low custom duties and land rental incentives. In June 2013, Vietnam had a total of 289 industrial zones with a combined surface of over 81,000 ha, attracting 4,665 FDI projects of more than 70 billion USD (Vietnam Ministry of Planning and Investment, 2013). These industrial zones are the main source for export cargo and raise the demand for land-driven dry ports in view of optimizing logistics efficiency, simplifying customs procedures and reducing externalities.

Another strength of dry port development in Vietnam is government support and land use availability. For the period from 2011 until 2020, the government has designated an area of 450 to 550 ha for building new dry ports, including 110-160 ha in the North, 90-120 ha in the Central and 260-270 ha in the South. In terms of transport infrastructure, the road system has been upgraded to meet transport demand and the requirements of the Trans-Asia Highway project initiated by UNESCAP. The natural river system gives the country a huge potential to develop inland waterways in all three regions. The rail system is still underdeveloped but has possibility to develop to link dry ports and seaports.

Vietnam can benefit from lessons and experiences of other nations in the world. Academic researches and venture projects should be carried out to extract best practices from suitable case studies.

\subsection{Weaknesses}

Vietnam has a lack of deep-water ports to accommodate big vessels. Poor facilities and short quay lengths led to a low port performance. The inland transportation is too dependent on road transport. Road haulage has a share of 95 percent in the modal split in the North, 99 percent in the Central part and 60-70 percent in the South. The river system in the North is not as good as in the South due to natural restrictions. In all regions, the role of rail transport is insignificant as the infrastructure is poor and does not meet the international standards of the Trans-Asian Railway project. Rail operations are dominated by state owned enterprises, which led to low competition and a lack of funding. In order to solve the 
financing problem, Vietnam wants to attract investment from the private sector but the current institutional framework limits the possibilities in this area. The current institutional framework of railways needs to be reformed to reduce risks and guarantee the return of private investors.

There are also many problems at the level of the institutional framework for dry port development. The Decision 2223/QD-TTg on 13/11/2011 of "Decision number 2223/QD-TTG of Prime Minister: with regards to planning Vietnam dry port system to 2020 , oriented to 2030" was the only institutional guidance after most ICDs started operations. The Decision sets the standards for establishing new ICDs, divides responsibilities of dry port development for different governmental bodies, and sets out a target for dry port planning in each region of the country. However, the locations of targeted dry ports and financing issues were not discussed in the Decision. The roles of current dry ports are not clarified in the planning exercise. That led to the hesitation of private investors and local governments. In fact, very few ICD projects were submitted since the Decision was issued.

Another weakness comes from the fact that most ICDs in Vietnam were formed spontaneously without macro planning and often leading to network inefficiency. In the North, most of ICDs are small and scattered with an area of less than 10 ha. The infrastructure and equipment in ICDs are poor, so is the management and human resources. Meanwhile in the South, too many small ICDs are concentrated in a small area along Sai Gon River. This has led to an overly competitive environment. The distinction of ICDs and logistics centers as discussed earlier also prevents the centralization of the inland node system in view of benefiting from economies of scale in logistics activities.

Another challenge for Vietnam dry port development is the poor cross-sector/organization collaboration in the logistics sector. According to the Commercial Law, logistics-related service provision is under control of numerous institutional bodies, such as the Ministry of Industry and Trade, the Ministry of Transport, the Ministry of Information and Communication, etc. However the existing collaboration among institutional bodies and between government and private organizations is loose due to overlapping responsibilities and excessive bureaucracy. Additionally, there is almost no horizontal collaboration between dry ports and other actors, such as seaport authorities, industrial zone managers, and rail operators.

Other weaknesses of the transport system in Vietnam are the poor ICT system and the lack of synchronization between the information systems used be different parties in the supply chain. The system in place for collecting information and statistics is outdated which leads to a lack of data and unreliable analyses. The shortage of academic research also contributes to poor freight forecasting. 


\subsection{Opportunities}

One of the biggest opportunities for developing dry ports in Vietnam is the gradual shift in focus of multinational corporations from China and India to South East Asia (SEA). According to Song (2014), the total foreign direct investment (FDI) in ASEAN 5 (i.e. Indonesia, Malaysia, Philippines, Singapore and Thailand) in 2013 was higher than in China. In 2012, SEA had a population of 617 million, higher than the EU (504 million) and almost doubles the size of the US (314 million). This population provides not only a huge pool of employment but also a big market for multinational companies. The increasing inflow of FDI into SEA nations, in particular Vietnam, will generate more cargo flows from/to the hinterland, and increase the need for mid-range inland terminals.

Another facilitating factor in the region are the Free Trade Agreements (FTAs) established by the Association of Southeast Asian Nations (ASEAN). The duty rates among all ASEAN members will become zero by 2018 with the latest adoption by Vietnam, Laos, Cambodia and Myanmar (the effective date for the remaining countries is 2015). The FTAs will merge all markets of ASEAN members into one and extract competitive advantages, leading to increased cargo flows by sea and in the hinterland. Additionally, the Vietnamese government is putting efforts to speed up the privatization of state-owned enterprises to "transform the current monopoly and subsidized power situation with a competitive power-generation market" (Lamont, 2012). In recent years, the government provides tax incentives and customs duty and land rental incentives to encourage more FDI in specific sectors and areas.

Another opportunity for dry port development lies in the ongoing deregulation and privatization of transport infrastructure by the Vietnamese government. Since joining the World Trade Organization (WTO) in 2007, Vietnam has committed to allow business ventures with an investment proportion of $49 \%$ vs. $51 \%$ in the areas of logistics and transport. Since 2014, the highest possible investment part of foreign partners increased to 100 percent. At the moment, Vietnam National Shipping Lines (VINALINES), the largest state owned shipping company in Vietnam has successfully equitized six of its member ports, including Khuyen Luong, Quy Nhon, Hai Phong, Nha Trang, Da Nang and Quang Ninh. VINALINES is on the way to put the ports of Nghe Tinh, Sai Gon, Nam Can, Cam Ranh and Can Tho into the initial public offering and finally equitize the mother company. That opens chances for upgrading the transportation system using private financing and management experience.

In terms of seaport investment and operation, Lach Huyen in North Vietnam is under construction with the investment of 1.2 billion USD by the Japanese investor ODA and the Vietnamese government. The project is expected to make Hai Phong into an international 
gateway seaport with a total throughput of 146-176 million tons per year by 2020, and the ability of receiving ships of up to 8000 TEU. In the South of Vietnam, the international gateway port Cai Mep - Thi Vai was put into operation in January 2014. Cai Mep - Thi Vai port is able to handle a throughput of 700,000 TEU per year. These seaport projects are expected to lower Vietnam's reliance on transhipment via Singapore and to generate more cargo flows in the hinterland and thus more demand for dry port development.

\subsection{Threats}

The biggest threat for dry port development in Vietnam is the competition from other nations in the SEA region in terms of maritime freight and FDI. Singapore is the dominant player when it comes to attracting FDI, while Vietnam, Thailand, Indonesia and Malaysia are getting more or less the same FDI shares. Any policy change in one nation might influence the position of the other nations in SEA. While Singapore already is a more knowledge-based economy, Thailand, Malaysia and Indonesia are putting efforts to have more investment in research and development, innovation and other high skilled production, which is threatening the position of Vietnam.

With regards to maritime freight, the Vietnamese port system is challenged by other international ports in the area. The huge operating loss of VINALINES, the biggest state owned shipping line and terminals operator in Vietnam, in recent years is threatening the position of Vietnam ports and fleet in the region. As result, the country might lose part of its market to other nations in the area. Another threat included is the conflict with China in the South China Sea, which influences the political balance between the two nations.

\section{Recommendations Linked To The Case Study}

The following recommendations are critical points to be considered in order to utilize the strengths, reduce the weaknesses, grasp the opportunities and create solutions for any coming challenges.

\subsection{Improve the institutional framework and guidance for dry port investment and operations}

Decision 2223/QD-TTg of the Prime Minister is the only institutional guidance for dry 
port development until now in Vietnam. In order to promote dry port investment and development, the institutional framework needs to be further detailed to clarify the following issues:

- Definition, role and functions of dry ports

- The duties of different governmental bodies involved in dry port planning and development and their coordination mechanisms.

- Conditions for setting up a dry port

- Forms of government support for dry port development

The role of existing dry ports should be clarified as well. The locations of dry port planning should be defined with high priority to give the basis for ministries and local governments to take actions. It should be based on thorough research since it is too costly to relocate facilities in the short term. Dry port location is much more complex than just cost and benefit approach as it concerns numerous and diverse factors driven by different stakeholders, such as operators, users, logistics providers, transport firms, freight forwarders, local governments and residents, road users, etc. The new planning locations should complement existing transport infrastructure and other seaport and inland transport planning. Room for expansion in the longer term should be seriously considered as well to avoid conflicts with other land use planning (as happened with existing ICDs).

\subsection{Develop intermodal dry ports: oriented to extended gate system}

As mentioned before, the concept of extended gate system releases the problems of congestion and pollution in seaports and improves the efficiency of cargo movement in relation to the hinterland. The key component of the system is the high integration between seaport terminals and inland locations through highly frequent and high-capacity transport corridors between the two nodes. In the system, customers can leave/pick up their containers at the inland terminals as if they are directly at the gates of the deepsea terminals in the seaports. For dry port planning in Vietnam, it is imperative to understand and apply this concept into practice by introducing rail or barge shuttles between dry ports and seaports based on three main values: high capacity, reliability and frequency.

The dependency on road transport in Vietnam results in a limitation of the main functions of dry ports to that of clearance depot and consolidation point. Most ICDs in the country do not have connections to the seaport terminals via rail. Only few ICDs in the South have the combination of truck and barges. In dry port planning, intermodality should play a center role in order to improve logistics efficiency, reduce congestion and pollution 
at seaports and in the hinterland network. Vietnam has the advantage of having a natural inland navigation system and good practice in some ICDs in the South. The inland navigation system can be more intensively used to bring containers from/to seaports over long distances to the hinterland, while trucking is the best choice to cover shorter distances from/to customers. In the long run, rail transport is the best solution to provide high capacity transportation in Vietnam. Despite the fact that the railway network in Vietnam is part of Trans-Asia Railway project, its development is lagging behind due to financing problems. The political framework related to this sector should be reformed to attract private investment in this sector.

\subsection{Dry port model to develop: hub and spoke inland node network}

Dry ports in Vietnam are mostly land-driven given their aim to serve industrial zones and some local markets. Shippers are mostly small and medium sized and inland transport infrastructure is limited. Given these side constraints, we propose the hub-and-spoke model for developing the dry port network at the macro planning level. Small and medium ICDs and logistics centers can be developed in close proximity of inland markets to give shippers the best services and accessibility. A few large dry ports can be developed along national economic corridors, utilizing intermodality, to consolidate/deconsolidate containers from/to local ICDs and forward them to seaports. The main advantage of this approach is that the transport infrastructure along these economic corridors has been researched and built (or going to be built) to complement the Trans-Asia Highway and Railway projects. In this way, existing ICDs could be used as local ICDs in the system and the one located close to corridors with high expansion ability could be used as the inland hub.

\subsection{Attract FDI in transport and promote Public Private partnerships (PPP)}

The biggest problem of developing dry ports in Vietnam is the lack of public funding. The best solution to overcome this problem is to open up the country for foreign investment. In recent years, the Vietnamese government speeded up the privatization of state-owned enterprises and promoted public private partnerships in many sectors, including transport. It is suggested that the government should accelerate its efforts to attract FDI in specific transport sectors. PPP arrangements in the transport sector, particularly for dry ports, will also improve the management ability in the sector and open clear opportunities for foreign investors. In general, the public sector should invest in the transport infrastructure connected to the dry port, while the private sector should take the 
responsibility of dry port investment and operations. Further research should help to identify the most suitable and feasible PPP model for dry port development in Vietnam.

\subsection{Improve cross sector/organizational collaboration}

Stakeholder management does not receive enough attention in Vietnam. Governance bodies' responsibilities in venture projects are not clarified and sometimes overlap each other. Profit-maximizing private actors could influence policy making through unfair lobbying activities. The collaboration between dry ports, seaports, rail operators and industrial zones is loose. In order to improve cross sectors/organizational collaboration in dry port projects, it is suggested to develop strategies to make all involved actors, including government bodies, private and public parties, stay committed and informed of the project.

\subsection{Strengthen the competitiveness of the seaport system}

Given growing competition from other ports in the area, it is high time to take actions to strengthen the competitiveness of the Vietnamese seaport system. Public private partnership should be promoted to replace the monopolies of state owned shipping lines and port operators. The two key projects in Lach Huyen port and Cai Mep - Thi Vai port should receive full support since they will secure the country's position as international gateway in South East Asia. The infrastructure of their hinterland network should be developed in line with seaport development.

\subsection{Improve research-based decision-making and ICT}

Dry port projects require a lot of research to make decisions, including traffic forecasts, location studies, freight mobility studies, customs clearance procedures, traffic planning and efficiency optimization, economic impact studies, environmental impact studies, etc. In view of the research work, it is necessary to improve the cooperation between decision makers and academic centers. Additionally, the advanced and synchronized information system should be developed to increase the integration between these nodes and to improve the cargo control over the hinterland network. 


\section{Conclusion}

Dry ports are being developed to increase the integration between gateway ports and the hinterland, thereby relieving some of the constraints at seaports. The paper has explained the reasons behind dry port emergence and development, namely seaport constraints, hinterland access and economic zone facilitation. By classifying dry ports and exploring primary functions of those locations, the paper contributes to the literature on dry port network development. In accordance with the regionalization phase, seaports are challenged to develop dry ports mid-range or in the distant hinterland to facilitate the integration with the hinterland and to compete with other ports in overlapping inland markets. The chosen inland locations ideally have advantages of land availability, government support, a good location for distributing activities, as well as the potential of having flexible, reliable and high capacity corridors in place. Gateway ports should also cooperate with land-driven dry ports since these nodes are the gates to access huge inland markets. The public should consider dry port development as part of macro strategies to improve logistics efficiency of inland transport and avoid negative effects linked to overinvestment or waste of resources.

The case study about Vietnam revealed the common difficulties developing countries are facing in order to develop their dry port system. Most ICDs were formed spontaneously without any form of macro planning, which typically led to a poor allocated location, an overreliance on road transport, outdated facilities and a low management efficiency. Other issues include a low financial ability, excessive bureaucracy and a lack of researches to support inland transport planning. Based on the SWOT analysis, the paper demonstrated that the key factors for successful developing the inland node systems in Vietnam relate to (i) the improvement of the institutional framework and guidance for dry port investment and operations; (ii) the creation of high capacity transport corridors based on reliability and frequency; (iii) the promotion of public private partnerships and cross sectors/ organizational collaboration; (iv) the strengthening of the competitiveness of the seaports system and (v) investments in research. The hub-and-spoke model can serve as a base model for the development of the dry port network in Vietnam. The small ICDs and logistics centers should be located in close proximity of scattered industrial zones and local market and are connected to the main dry port hubs. Dry port hubs are large and should locate along the main economic corridors to fully benefit from the advantages of port-hinterland intermodality. 


\section{References}

Caballini, C. and Gattorna, E., 2009. The expansion of the port of Genoa: the Rivalta Scrivia dry port. Transport and Communications Bulletin for Asia and the Pacific, $78,103-125$.

Cronje, E., Matthee, M. and Krugell, W., 2009. Trade and transport cost: the role of dry port in South Africa. Transport and Communications Bulletin for Asia and the Pacific , 78, 161-173.

Economic Commission for Europe, 1998. UN/LOCODE-Code for Ports and other Locations, Recommendation 16, Geneva.

Economic Commission for Europe. 2001. Terminology on Combined Transport, United Nations, New York and Geneva.

Garnwa, P., Beresford, A. and Pettit, S., 2009. Dry port: a comparative study of the United Kingdom and Nigeria. Transport and Communications Bulletin for Asia and Pacific, 78, 58-81.

Jarzemskis, A. and Vasiliauskas, A. V., 2007. Research on dry port concept as intermodal node. Transport, 22(3), 207-213.

Lamont, G, 2012. Southeast Asia Investment Opportunities - Tax \& Other Incentives. Retrieved 8th April 2014 from http://www.pwc.com/th/en/publications/download/south-east-asia-web.pdf

Monios, J. and Wang, Y., 2013. Spatial and institutional characteristics of inland port development in China. GeoJournal, 78, 897-913.

Monios, J. and Wilmsmeier, G., 2012. Giving a direction to port regionalization. Transportation Research Part A, 46, 1551-1561.

$\mathrm{Ng}, \mathrm{A} . \mathrm{K}$ and Cetin, I. B., 2012. Locational characteristics of dry ports in developing economies: some lessons from Northern India. Regional Studies, 46(6), 757-773. 
$\mathrm{Ng}, \mathrm{A} . \mathrm{K} . \mathrm{Y}$. and Gujar, G., 2009. The spatial characteristics of dry ports in India. Transport and Communications Bulletin for Asia and the Pacific, 78, 147-160.

Notteboom, T. and Rodrigue, J., 2005. Port regionalization: toward a new phase in port development, Maritime Policy \& Management, 32(3), 297-313.

Notteboom, T. and Rodrigue, J., 2009. Inland Terminals within North America and European supply chains. Transport and Communications Bulletin for Asia and the Pacific , 78, 1-57.

Nguyễn Thanh Thủy, 2010. Thực trạng và tiềm năng của hệ thống cảng Việt Nam (Conditions and potentials of the port system in Vietnam). Published by Vietnam Maritime University.

Rodrigue, J. and Notteboom, T., 2009. The terminalization of supply chains: reassessing the role of terminals in port/hinterland logistical relationship. Maritime Policy \& Management. 36(2), 165-183.

Roso, V., 2005. The dry port concept - applications in Sweden. Proceedings of Logistics Research Network, Plymouth: International Logistics and Supply Chain Management.

Roso, V., Woxenius, J. and Lumsden, K., 2009. The dry port concept: connecting container seaports with the hinterland. Journal of Transport Geography, 17, 338-345.

Song, S., 2014. Southeast Asia Receives More Foreign Direct Investment (FDI) Than China, Which Is Now The World's Third-Largest Foreign Investor. Retrieved 14th May 2015 from

http:/www.ibtimes.com/southeast-asia-receives-more-foreign-direct-investment-f di-china-which-now-worlds-third-largest

The World Bank, 2014. Container port traffic. Retrieved September 24, 2014 from: http://data.worldbank.org/indicator/IS.SHP.GOOD.TU

UNCTAD, 1982. Multimodal Transport and Containerization. TD/B/C.4/238/supplement 1, Part Five: Ports and Container Depots. 
UNCTAD, 1991. Handbook on the Management and Operation of Dry Ports. UNCTAD/RDP/LDC/7, Geneva.

UNESCAP, 2014. Seminar on Capacity - Building for the Development and Operation of Dry Ports of International Importance. Bangkok. Retrieved April 30, 2014 from: http://www.unescap.org/sites/default/files/6.6.LaoPDR.pdf

Veenstra, A., Zuidwijk, R. and Asperen, E., 2012. The extended gate concept of container terminals: Expanding the notion of dry ports. Maritime Economics \& Logistics, $14,14-32$.

Vietnam Ministry of Planning and Investment, 2013. FDI Attraction in Industrial Parks and Economic Zones in First Six Months of 2013. Retrieved 14 May 2015 from http://en.business.gov.vn/tabid/133/catid/590/item/12593/fdi-attraction-in-industri al-parks-and-economic-zones-in-first-six-months-of-2013.aspx

Vietnam Ministry of Transport, 2010. Quy hoạch phát triển hệ thống cảng cạn: Báo cáo tổng hợp (Planning dry ports system development: Synthesis report).

Vietnam Ministry of Transport, 2013. Báo cáo tổng hợp về việc điều chỉnh chiến lược phát triển giao thông vận tải Việt Nam đến năm 2020 và tầm nhìn đến năm 2030 (Synthesis report with regards to adjustments of planning to develop Vietnam transport until 2020 and oriented to 2030).

Vietnam Prime Minister, 2011. Quyết định số 2223/QĐ-TTG của Thủ tướng Chính phủ: Về việc Quy hoạch phát triển hệ thống cảng cạn Việt Nam đến năm 2020, định hướng đến năm 2030" (Decision number 2223/QD-TTG of Prime Minister: with regards to planning Vietnam dry port system to 2020, oriented to 2030) 